\title{
A CSAPADÉK VÁLTOZATOSSÁGÁNAK VIZSGÁLATA
}

\author{
Manninger Miklós \\ NAIK Erdészeti Tudományos Intézet
}

\begin{abstract}
Kivonat
A csapadék térbeli változatosságának kérdése elsősorban a nem helyben mért adatok felhasználásakor merül fel, míg az időbeli változatosság megismerése a prognosztizált változások értelmezéséhez nyújt alapot. A kiválasztott, legalább 100 éves adatsorok értékelését a havi mellett hidrológiai év bontásban, illetve a Járó-féle vizzorgalmi időszakoknak megfelelöen is elvégeztem, és az elemzéseket a meteorológusok által referencia időszakként kezelt 30 éves periódusokra is kiterjesztettem. A statisztikai mutatók közül elsősorban a variációs együttható (CV) változását mutatom be. Megállapítottam, hogy a rövidebb időszakok (1-3 hónap) átlaga nem jó jellemzöje az adatsornak, mert a CV lényegesen meghaladja a 30\%-ot, míg a hosszabb időszakra vonatkozó átlag megbízhatóbbá válik. A 30 éves referencia időszakok vízforgalmi időszakokra vonatkozó CV-értékei az idővel általában inkább csökkennek, azaz az időszaki csapadék mennyisége általánosságban nem vált szélsőségesebbé. Még az időszaki csapadék változatossága is olyan mértékü, hogy az átlagtól való $\pm 20 \%-0 \mathrm{~s}$ eltérés is az interkvartilis terjedelembe esik, tehát az ilyen léptékủ változás sem nevezhető szélsőségesnek.
\end{abstract}

Kulcsszavak: csapadék, térbeli és időbeli változatosság, variációs együttható (CV), interkvartilis terjedelem.

\section{INVESTIGATION OF THE VARIATION OF PRECIPITATION}

\begin{abstract}
The issue of the spatial variation of precipitation can be important in case of using non-locally measured data, while the knowledge about the variation in time is necessary for the interpretation of the predicted changes. At least 100 -year-long data series were selected and analysed according to different time window (from monthly over the different water cycle periods to hydrological year). The 30 year reference periods used by climatologists were also taken into account.. From the statistical evaluation the results connected with the variation coefficient $(\mathrm{CV})$ are shown primarily. The author stated that the mean of the shorter periods (1-3 months) is not a good parameter ( $\mathrm{CV}>>30 \%$ ), while the mean for longer period is more reliable. Generally, the CV of the water cycle periods of the 30-year-reference periods decreases as time goes on. It means that the amount of precipitation hasn't become more extreme. Even the variation of water cycle periods is so large that $\pm 20 \%$ deviation from mean is still in the interquartile range, thus this kind of change in precipitation cannot be named as extreme.
\end{abstract}

Keywords: precipitation, variation in time and space, variation coefficient (CV), interquartile range. 


\section{BEVEZETÉS}

A vizsgálat az ERTI és a Nebih Erdészeti lgazgatósága által 2012-ben kidolgozott éghajlat-változási monitoring koncepcióban felsorolt elemzési feladatok közé tartozott. Az elemzések a koncepció részletesebb megalapozását szolgálták, s mivel többségükben a meteorológiai tényezők, köztük elsősorban a csapadék, és más erdészeti jellemzők (egészségi állapot, kárositás, növedék, stb.) összefüggéseit vizsgálták, indokolttá vált a csapadék természetének alaposabb megismerése is.

A csapadék változatossága térben és időben egyaránt megjelenik. $A$ térbeli változatosság kérdése elsősorban a nem helyben mért adatok felhasználásakor merül fel. Az időbeli változatosság megismerése a prognosztizált változások értelmezéséhez, a következmények reális súlyának megitéléséhez nyújt alapot.

\section{ANYAG ÉS MÓDSZER}

A hosszú távú adatsorok szükségessége miatt a vizsgálatot elsősorban az OMSZ és a vízügy adataiból előállított adatsorokon lehetett elvégezni. A legalább 100 éves időszakot felölelö adatsorokat a nyilvánosan elérhető adatforrások (Hajósy et al. 1975, Vízrajzi évkönyvek, Időjárási havijelentések) felhasználásával, illetve az Országos Vízügyi Főigazgatóság 2007-2012 közötti időszakra vonatkozó adatközlése alapján állítottam elő. A források jellegéből adódóan az előállított adatbázis havi adatokat tartalmaz.

A mérőállomások közül azokat használtam fel, melyeknek adatai legalább 1901-töl (1900-tól) rendelkezésre állnak, illetve ahol az állomások történeti leírása, valamint az állomások nyilvántartási adatai szerint mérést befolyásoló áthelyezés nem történt. A HajósyKakas-Kéri által jelzett, a mérőeszközökkel összefüggö mérési hiba szerint az adatokat javítottam. A föleg a világháborúk miatt elmaradt méréseknél a szerzők által a környező állomások adataiból interpolált hiánypótlást elfogadtam.

A fenti feltételeknek eleget tevő állomások száma erősen korlátozott és - érdekes módon - elsősorban a kisebb településekhez köthetőek, míg a nagyobb városok (pl. Debrecen, Szeged) szintén hosszú, olykor az 1870-es évekig visszanyúló adatsorai többnyire többször áthelyezett mérōállomásokról származnak. Az előállított 33 adatsor (30 teljes + 3, pár évvel rövidebb) a 10 kevésbé homogén nagyvárosi adatsorral kiegészítve, ha nem is egyenletesen, de lefedi az országot. 
1. táblázat: A vizsgálatban felhasznált állomások listája erdőgazdasági tájak szerint, szürke háttérrel kiemelve a legkevésbé változóakat.

Table 1: List of stations grouped by forest regions, the most reliable ones are highlighted.

\begin{tabular}{|c|c|c|c|c|c|c|}
\hline \multirow{2}{*}{ erdőgazdasági táj } & \multirow{2}{*}{ mérőhely } & \multirow{2}{*}{\begin{tabular}{|c|} 
tszfm \\
$m$ \\
\end{tabular}} & \multicolumn{2}{|c|}{ földrajzi } & kezdő & záró \\
\hline & & & szélesség & hosszúság & \multicolumn{2}{|c|}{ év } \\
\hline \multicolumn{7}{|l|}{ I Nagyalföld } \\
\hline 1. Szatmár-Beregi-síkság & Vásárosnamény & 114 & 48,133 & 22,313 & 1900 & 2012 \\
\hline 2. Bodrogköz-Rétköz & Tiszabercel & 102 & 48,167 & 21,669 & 1901 & 2012 \\
\hline 3. Nyírség & Debrecen & 133 & 47,484 & 21,635 & 1900 & 2012 \\
\hline 3. Nyírség & Téglás & 144 & 47,717 & 21,687 & 1901 & 2012 \\
\hline 7. Nagykunság & Túrkeve & 87 & 47,105 & 20,734 & 1900 & 2012 \\
\hline 10. Alsó-Tiszai-ártér & Szeged & 79 & 46,258 & 20,085 & 1900 & 2012 \\
\hline 12. Duna-Tisza közi hátság & Ásotthalom & 117 & 46,197 & 19,786 & 1900 & 2012 \\
\hline 12. Duna-Tisza közi hátság & Soltvadkert & 116 & 46,595 & 19,348 & 1901 & 2012 \\
\hline 15. Mezőföld & Tengelic & 120 & 46,532 & 18,722 & 1901 & 2012 \\
\hline \multicolumn{7}{|l|}{ II. Északi-középhegység } \\
\hline 17. Eperjes-Tokaji-hegyvidék & Tarcal & 115 & 48,147 & 21,332 & 1901 & 2012 \\
\hline 20. Heves-Borsodi-dombság & Bélapátfalva & 318 & 48,054 & 20,349 & 1901 & 2012 \\
\hline 20. Heves-Borsodi-dombság & Sáta & 276 & 48,180 & 20,406 & 1901 & 2012 \\
\hline 21. Bükk & Bogács & 186 & 47,899 & 20,532 & 1901 & 2012 \\
\hline 21. Bükk & Kisgyőr & 173 & 47,987 & 20,669 & 1900 & 2012 \\
\hline 22. Mátra & Ecséd & 157 & 47,735 & 19,781 & 1901 & 2012 \\
\hline 23. Gödöllöi-dombság & Gödöllö & 221 & 47,602 & 19,380 & 1900 & 2012 \\
\hline 24. Cserhát-vidék & Terény & 204 & 47,953 & 19,449 & 1901 & 1999 \\
\hline 24. Cserhát-vidék & Tolmács & 196 & 47,936 & 19,114 & 1900 & 2012 \\
\hline 25. Börzsöny & Nógrád & 236 & 47,900 & 19,047 & 1900 & 2012 \\
\hline \multicolumn{7}{|l|}{ III. Dunántúli-középhegység } \\
\hline 27. Pilis-Budai-hegység & Páty & 194 & 47,513 & 18,848 & 1901 & 2012 \\
\hline 29. Vértes & Csákvár & 185 & 47,404 & 18,464 & 1901 & 2012 \\
\hline $\begin{array}{l}\text { 30. Dunazugi-medencék és } \\
\text { Velence-vidék }\end{array}$ & Szár & 201 & 47,485 & 18,517 & 1901 & 2012 \\
\hline 31. Vértes- és Bakonyalja & Ravazd & 131 & 47,515 & 17,773 & 1901 & 2012 \\
\hline 32. Magas-Bakony & Bakonybél & 267 & 47,253 & 17,726 & 1900 & 2012 \\
\hline 32. Magas-Bakony & Városlöd & 294 & 47,154 & 17,650 & 1900 & 2012 \\
\hline 35. Balaton-felvidék & Balatonalmádi & 110 & 47,032 & 18,021 & 1901 & 2001 \\
\hline \multicolumn{7}{|l|}{ IV. Kisalföld } \\
\hline 37. Győr-Tatai-teraszvidék & Ács & 120 & 47,715 & 18,035 & 1900 & 2012 \\
\hline 38. Szigetköz-Rábaköz & Beled & 133 & 47,470 & 17,110 & 1901 & 2012 \\
\hline 38. Szigetköz-Rábaköz & Győr & 119 & 47,684 & 17,622 & 1901 & 2012 \\
\hline 38. Szigetköz-Rábaköz & Mosonmagyaróvár & 122 & 47,886 & 17,269 & 1900 & 2012 \\
\hline 39. Fertő-Hanság-medence & Kapuvár & 118 & 47,684 & 16,996 & 1900 & 2012 \\
\hline 40. Marcal-medence & Kerta & 140 & 47,166 & 17,267 & 1901 & 2012 \\
\hline
\end{tabular}




\begin{tabular}{|c|c|c|c|c|c|c|}
\hline \multirow{2}{*}{ erdőgazdasági táj } & \multirow{2}{*}{ mérőhely } & \multirow{2}{*}{\begin{tabular}{|c|} 
tszfm \\
$m$
\end{tabular}} & \multicolumn{2}{|c|}{ földrajzi } & kezdő & záró \\
\hline & & & szélesség & hosszúság & \multicolumn{2}{|c|}{ év } \\
\hline \multicolumn{7}{|l|}{ V. Nyugat-Dunántúl } \\
\hline 42. Soproni-dombság & Sopron & 230 & 47,722 & 16,648 & 1900 & 2012 \\
\hline 45. Sopron-Vasi-síkság & Szombathely & 227 & 47,200 & 16,645 & 1900 & 2012 \\
\hline 46. Kemeneshát & Csehimindszent & 175 & 47,053 & 16,954 & 1901 & 2012 \\
\hline 47. Örség & Kercaszomor & 238 & 46,789 & 16,362 & 1901 & 2012 \\
\hline 47. Őrség & Szentgotthárd & 221 & 46,913 & 16,303 & 1900 & 2012 \\
\hline \multicolumn{7}{|l|}{ VI. Dél-Dunántúl } \\
\hline 49. Balatoni-medence & Tapolca & 125 & 46,881 & 17,447 & 1901 & 2012 \\
\hline 50. Külsö-Somogy & Tab & 177 & 46,735 & 18,014 & 1901 & 2012 \\
\hline 51. Belső-Somogy & Csurgó & 147 & 46,264 & 17,102 & 1901 & 2012 \\
\hline 52. Kelet-Zalai-dombság & Nagykanizsa & 138 & 46,459 & 16,964 & 1900 & 2012 \\
\hline 54. Tolnai-dombság & Szálka & 168 & 46,280 & 18,632 & 1900 & 2012 \\
\hline 55. Mecsek & Pécsvárad & 259 & 46,171 & 18,413 & 1901 & 2006 \\
\hline
\end{tabular}

A mérōállomások telepitéskori céljukból adódóan elsősorban települések, illetve mezőgazdasági területek közelében létesültek, tehát kevés az erdőterületet jellemző mérőállomás. Ez a mérőállomások tengerszint feletti magasságában is megjelenik, mert csak egy mérōállomás fekszik $300 \mathrm{~m}$ felett (Bélapátfalva, $318 \mathrm{~m}$ ). Mindezek ellenére úgy vélem, hogy a kiválasztott mérőállomások alkalmasak lehetnek az erdőgazdasági nagytájak csapadékváltozatosságának bemutatására is, és ezért ennek megfelelően csoportosítottam őket (1. táblázat). A térképen (1. ábra) a nagyvárosi állomásokat narancssárgával, a rövidebb adatsorú vagy kevésbé megbízható mérőhelyeket zölddel jelöltem.

A térbeli és időbeli változatosságot az elöbbiekben említett adatsorok összeállitása után statisztikai mutatókkal jellemeztem. A változatosság vizsgálatának legkisebb időegysége a gyakorlatot és az adatok hozzáférhetőségét szem előtt tartva - a hónap.

Az időbeli változatosság jellemzésére a mérőhelyek legalább 100 éves adatsorát felhasználva az alábbi statisztikai mutatókat alkalmaztam mérőhelyenként:

- havi minimum

- alsó kvartilis

- havi átlag és medián

- felső kvartilis

- havi maximum

- interkvartilis terjedelem: az a tartomány, amibe az adatok 50\%-a tartozik

- variációs együttható (CV): az adatok szórása az átlaghoz viszonyítva, \%-ban,

$$
C V=\frac{\sigma}{\bar{x}} \cdot 100
$$




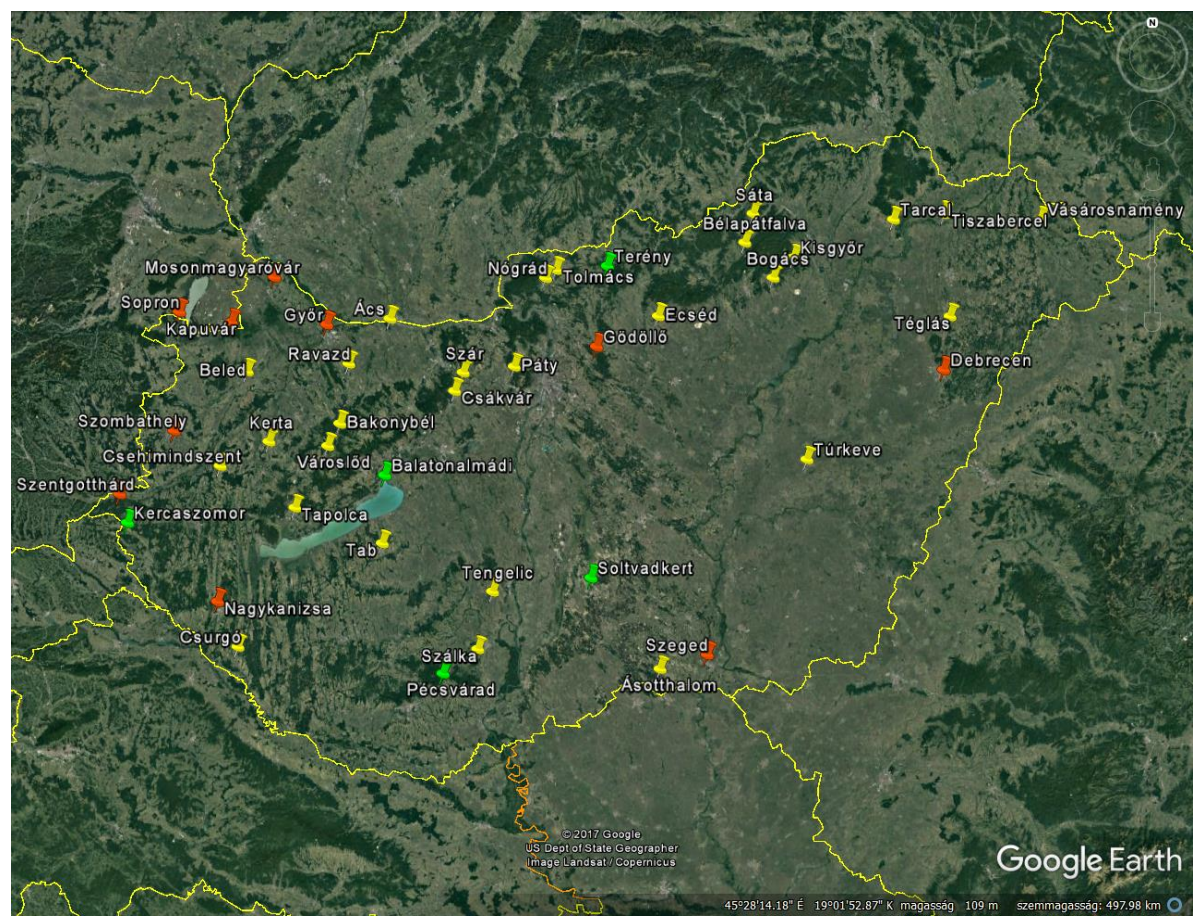

1. ábra: A csapadékmérő állomások elhelyezkedése.

Figure 1: Location of the stations.

A többi szóródási mutatóval szemben a variációs együttható vagy másképpen a relatív szórás a következő előnyökkel rendelkezik:

- elvonatkoztat a mértékegységektöl,

- elvonatkoztat a nagyságrendi viszonyoktól,

- segítségével megállapítható az átlag "jósága", tehát az hogy az átlag mennyire tipikus, mennyire áll közel az átlagolandó adatsorhoz.

Szász és Tökei (1997) szerint a csapadék változékonyságának legmegfelelöbb mutatója a variációs együttható. Dunkel et al. (1991) a variációs együtthatót alkalmazták a hazai agrometeorológiai állomáshálózat racionális sürűségének meghatározására. Előnyei miatt a csapadékviszonyok jellemzésére napjainkban is használják (Deka et al. 2013, Machiwal et al. 2017), de más szakterületen is alkalmazzák (Webb et al. 2017).

A CV kategóriáinak statisztikai értékelése (Huzsvai 2011):

- ha 10\% alatti, akkor az adatsor állandó (homogén), tehát az adatok egymáshoz és a belölük kiszámított átlaghoz közel állnak,

- ha 10-20\% közötti, akkor közepesen változékony,

- ha 20-30\%, akkor erősen változékony,

- ha 30\% feletti, akkor szélsőséges változékonyságú adatsorról beszélünk, ahol az átlag már nem jellemzi jól az adatsort. 
Az értékelést a havi mellett az erdő életfolyamataihoz illeszkedő hidrológiai év bontásban, illetve a Járó-féle (1989) vízforgalmi időszakoknak (XI-IV. hónap: tárolási, V-VII. hónap: fő vízfelhasználási, VIII-X. hónap: fenntartási) megfelelően is elvégeztem. Az elemzéseket a meteorológusok által referencia időszakként kezelt 30 éves periódusokra is kiterjesztettem, s a periódusokat 1941 -től kezdődően 10 éves lépésközökben mozgatva a statisztikai mutatók változását is vizsgáltam.

\section{EREDMÉNYEK ÉS MEGVITATÁSUK}

Az értékelést minden állomásra elvégeztem, de a következő fejezetekben többnyire csak kiragadott példákon mutatom be az összefüggéseket, illetve a statisztikai mutatók közül elsősorban a variációs együtthatót $(\mathrm{CV})$ és az interkvartilis terjedelmet vizsgálom.

Az összesen 43 mérőhelyböl előállított adatbázisból kivettem a költöztetések miatt bizonytalan városi és a rövidebb adatsorral rendelkező mérőhelyeket (Balatonalmádi, Terény), de a lefedettségi hiányok miatt megtartottam három, a kiválasztási feltételeknek nem teljesen megfelelö mérőállomást (Kercaszomor, Pécsvárad, Soltvadkert). Így összességében 31 méröhely adatsorait értékeltem.

\section{Variációs együttható (CV)}

Havi csapadékadatok

A havi CV-értékek 43-84\% között változnak a teljes vizsgált idöszakot (1901-2010) tekintve. A legkisebb értékek (lilával kiemelve) április-június hónapokban, a legnagyobbak (zöldes színnel kiemelve) októberben fordulnak elő (2. táblázat).

A 30 éves referencia időszakokban a CV-értékek többé-kevésbé hasonló képet mutatnak, de az időszakok rövidebb hosszából adódóan vannak eltérések. A teljes időszakhoz képest a legnagyobb változást az utolsó 30 éves időszak CV-értékei mutatják (3. táblázat), miközben a havi értékek 36-88\% között változnak. A júniusi minimum és az októberi (szeptemberi) maximum még meghatározó, de mind a minimumok, mind a maximumok jobban szóródnak.

Ha a CV kategóriáit vizsgáljuk, akkor megállapítható, hogy a havi csapadékadatok szélsőséges változékonyságú adatsorokat képeznek, vagyis átlaguk nem jó jellemző. Ez mind a 110 éves teljes időszakra, mind az összes 30 éves referencia időszakra érvényes. 
2. táblázat: A havi CV-értékek változása a teljes vizsgált időszakban (1901-2010) az erdőgazdasági nagytájak szerint csoportositott mérőállomásokon.

Table 2: The changes of the monthly CV in the whole period (1901-2010), sorted by the forest regions.

\begin{tabular}{|c|c|c|c|c|c|c|c|c|c|c|c|c|c|}
\hline $1901-2010$ & tszfm & I. & II. & III. & IV. & V. & Vl. & VII. & VIII. & IX. & $\mathrm{X}$. & XI. & XII. \\
\hline Vásárosnamény & 114 & 55 & 60 & 72 & 59 & 48 & 54 & 57 & 57 & 64 & 76 & 54 & 52 \\
\hline Tiszabercel & 102 & 66 & 67 & 75 & 55 & 52 & 51 & 55 & 60 & 64 & 77 & 64 & 61 \\
\hline Téglás & 144 & 61 & 66 & 71 & 51 & 56 & 51 & 57 & 59 & 69 & 75 & 60 & 60 \\
\hline Túrkeve & 87 & 61 & 65 & 66 & 54 & 61 & 50 & 63 & 69 & 69 & 81 & 67 & 62 \\
\hline Ásotthalom & 117 & 59 & 66 & 64 & 55 & 63 & 58 & 67 & 67 & 74 & 79 & 67 & 60 \\
\hline Soltvadkert & 116 & 61 & 72 & 65 & 53 & 58 & 53 & 64 & 61 & 71 & 75 & 65 & 58 \\
\hline Tengelic & 120 & 59 & 73 & 61 & 54 & 55 & 51 & 60 & 68 & 69 & 81 & 62 & 58 \\
\hline Tarcal & 115 & 67 & 66 & 74 & 56 & 55 & 52 & 56 & 65 & 72 & 77 & 64 & 60 \\
\hline Bélapátfalva & 318 & 70 & 73 & 71 & 51 & 56 & 52 & 60 & 66 & 65 & 82 & 66 & 63 \\
\hline Sáta & 276 & 70 & 67 & 70 & 52 & 55 & 51 & 57 & 66 & 65 & 79 & 63 & 61 \\
\hline Bogács & 186 & 63 & 71 & 69 & 56 & 58 & 53 & 59 & 66 & 71 & 82 & 63 & 63 \\
\hline Kisgyőr & 173 & 72 & 77 & 73 & 56 & 61 & 59 & 63 & 67 & 73 & 84 & 64 & 67 \\
\hline Ecséd & 157 & 62 & 73 & 67 & 52 & 57 & 63 & 63 & 67 & 70 & 80 & 62 & 57 \\
\hline Tolmács & 196 & 56 & 64 & 67 & 54 & 56 & 53 & 59 & 69 & 71 & 74 & 59 & 54 \\
\hline Nógrád & 236 & 55 & 61 & 71 & 52 & 58 & 56 & 57 & 67 & 74 & 78 & 56 & 56 \\
\hline Páty & 194 & 51 & 64 & 69 & 51 & 56 & 59 & 64 & 69 & 72 & 77 & 66 & 55 \\
\hline Csákvár & 185 & 53 & 67 & 64 & 53 & 52 & 60 & 69 & 64 & 69 & 73 & 62 & 54 \\
\hline Szár & 201 & 49 & 67 & 70 & 51 & 60 & 67 & 66 & 68 & 69 & 76 & 62 & 53 \\
\hline Ravazd & 131 & 52 & 68 & 65 & 60 & 61 & 59 & 59 & 62 & 69 & 70 & 60 & 52 \\
\hline Bakonybél & 267 & 55 & 65 & 60 & 59 & 65 & 60 & 71 & 67 & 71 & 76 & 60 & 55 \\
\hline Városlöd & 294 & 53 & 62 & 64 & 54 & 65 & 50 & 65 & 57 & 66 & 73 & 57 & 54 \\
\hline Ács & 120 & 52 & 66 & 68 & 57 & 59 & 59 & 62 & 59 & 71 & 72 & 64 & 54 \\
\hline Beled & 133 & 56 & 65 & 62 & 60 & 55 & 52 & 54 & 57 & 60 & 66 & 59 & 53 \\
\hline Kerta & 140 & 56 & 66 & 64 & 55 & 53 & 54 & 62 & 59 & 62 & 73 & 60 & 54 \\
\hline Csehimindszent & 175 & 62 & 73 & 63 & 58 & 61 & 49 & 58 & 58 & 64 & 67 & 61 & 53 \\
\hline Kercaszomor & 238 & 71 & 73 & 57 & 56 & 49 & 43 & 54 & 50 & 63 & 67 & 62 & 58 \\
\hline Tapolca & 125 & 61 & 74 & 67 & 56 & 51 & 55 & 63 & 63 & 63 & 74 & 62 & 57 \\
\hline Tab & 177 & 63 & 72 & 64 & 53 & 55 & 54 & 62 & 64 & 64 & 75 & 61 & 54 \\
\hline Csurgó & 147 & 58 & 65 & 61 & 54 & 54 & 49 & 60 & 62 & 62 & 69 & 61 & 55 \\
\hline Szálka & 168 & 57 & 69 & 63 & 55 & 53 & 56 & 59 & 65 & 70 & 75 & 64 & 55 \\
\hline Pécsvárad ${ }^{*}$ & 259 & 55 & 65 & 62 & 50 & 57 & 51 & 64 & 64 & 74 & 74 & 65 & 56 \\
\hline
\end{tabular}

* Pécsvárad adatsorából hiányzik a 2007-2010 közötti időszak 
3. táblázat: A havi CV-értékek változása az 1981-2010 közötti 30 éves referencia időszakban az erdőgazdasági nagytájak szerint csoportositott méröállomásokon.

Table 3: The changes of the monthly CV in the reference period 1981-2010, sorted by the forest regions.

\begin{tabular}{|c|c|c|c|c|c|c|c|c|c|c|c|c|c|}
\hline $1981-2010$ & tszfm & I. & II. & III. & IV. & V. & VI. & VII. & VIII. & IX. & $X$ & XI. & XII. \\
\hline Vásárosnamény & 114 & 48 & 56 & 74 & 54 & 51 & 48 & 62 & 56 & 64 & 66 & 51 & 48 \\
\hline Tiszabercel & 102 & 48 & 63 & 74 & 61 & 58 & 47 & 53 & 62 & 58 & 74 & 55 & 59 \\
\hline Téglás & 144 & 51 & 63 & 65 & 51 & 56 & 56 & 61 & 67 & 66 & 74 & 53 & 59 \\
\hline Túrkeve & 87 & 65 & 63 & 61 & 58 & 64 & 43 & 65 & 81 & 64 & 76 & 68 & 61 \\
\hline Ásotthalom & 117 & 64 & 63 & 56 & 57 & 78 & 65 & 65 & 59 & 68 & 73 & 63 & 62 \\
\hline Soltvadkert & 116 & 74 & 67 & 51 & 50 & 66 & 57 & 62 & 66 & 78 & 69 & 60 & 59 \\
\hline Tengelic & 120 & 68 & 69 & 50 & 55 & 63 & 50 & 54 & 65 & 78 & 71 & 53 & 54 \\
\hline Tarcal & 115 & 54 & 63 & 71 & 60 & 58 & 45 & 66 & 69 & 60 & 68 & 57 & 56 \\
\hline Bélapátfalva & 318 & 64 & 68 & 62 & 59 & 67 & 47 & 64 & 63 & 64 & 76 & 59 & 69 \\
\hline Sáta & 276 & 68 & 65 & 63 & 61 & 60 & 48 & 61 & 56 & 65 & 69 & 53 & 72 \\
\hline Bogács & 186 & 61 & 65 & 61 & 60 & 67 & 48 & 65 & 66 & 67 & 79 & 56 & 63 \\
\hline Kisgyőr & 173 & 66 & 67 & 70 & 63 & 63 & 55 & 63 & 70 & 71 & 83 & 53 & 70 \\
\hline Ecséd & 157 & 71 & 67 & 51 & 58 & 68 & 67 & 76 & 67 & 70 & 67 & 52 & 60 \\
\hline Tolmács & 196 & 54 & 57 & 58 & 60 & 60 & 46 & 60 & 69 & 74 & 64 & 47 & 61 \\
\hline Nógrád & 236 & 57 & 58 & 61 & 62 & 71 & 52 & 59 & 70 & 79 & 68 & 46 & 65 \\
\hline Páty & 194 & 54 & 65 & 52 & 61 & 70 & 55 & 75 & 68 & 79 & 70 & 46 & 60 \\
\hline Csákvár & 185 & 60 & 68 & 53 & 62 & 55 & 54 & 67 & 63 & 73 & 73 & 54 & 60 \\
\hline Szár & 201 & 53 & 68 & 53 & 59 & 75 & 66 & 70 & 66 & 76 & 68 & 46 & 61 \\
\hline Ravazd & 131 & 57 & 72 & 59 & 72 & 71 & 55 & 56 & 60 & 75 & 68 & 47 & 56 \\
\hline Bakonybél & 267 & 60 & 72 & 58 & 58 & 88 & 52 & 67 & 76 & 79 & 64 & 49 & 61 \\
\hline Városlőd & 294 & 57 & 66 & 50 & 53 & 76 & 42 & 53 & 55 & 77 & 65 & 46 & 56 \\
\hline Ács & 120 & 53 & 71 & 55 & 65 & 70 & 57 & 50 & 53 & 75 & 69 & 49 & 59 \\
\hline Beled & 133 & 57 & 73 & 49 & 62 & 51 & 41 & 58 & 56 & 67 & 64 & 49 & 49 \\
\hline Kerta & 140 & 61 & 67 & 56 & 55 & 44 & 41 & 52 & 54 & 63 & 66 & 51 & 54 \\
\hline Csehimindszent & 175 & 65 & 70 & 59 & 50 & 46 & 41 & 52 & 56 & 63 & 68 & 55 & 52 \\
\hline Kercaszomor & 238 & 78 & 66 & 57 & 57 & 42 & 36 & 47 & 52 & 54 & 67 & 57 & 53 \\
\hline Tapolca & 125 & 65 & 73 & 56 & 57 & 53 & 44 & 52 & 76 & 71 & 65 & 56 & 57 \\
\hline Tab & 177 & 74 & 70 & 56 & 60 & 58 & 50 & 58 & 59 & 71 & 69 & 48 & 56 \\
\hline Csurgó & 147 & 75 & 55 & 52 & 52 & 51 & 45 & 46 & 57 & 58 & 66 & 56 & 56 \\
\hline Szálka & 168 & 66 & 69 & 45 & 51 & 61 & 65 & 50 & 68 & 79 & 68 & 56 & 56 \\
\hline Pécsvárad* & 259 & 64 & 56 & 43 & 49 & 67 & 55 & 68 & 51 & 82 & 64 & 55 & 62 \\
\hline
\end{tabular}

* Pécsvárad adatsorából hiányzik a 2007-2010 közötti időszak 


\section{Vízforgalmi időszakok}

Ha a CV értékeit a vízforgalmi időszakok szerint vizsgáljuk, akkor a havi adatsorokhoz képest valamivel kisebb értékeket kapunk, tehát a CV ebben az esetben kevésbé változékony statisztikai mutatónak bizonyul (4. táblázat).

A 4. táblázat CV-értékei jól mutatják, hogy a vizsgált időszak hosszának növekedésével a CV értékei csökkennek. A korábban ismertetett havi értékekhez képest a 3, illetve 6 hónapos időszakok csökkenő CV-értékein keresztül a hidrológiai évre vonatkozóan a teljes időszakra vonatkozóan az értékek már csak 16-24\% közöttiek, vagyis a hidrológiai éves adatsorok már a közepesen változékony, illetve változékony kategóriába esnek.

4. táblázat: A vizforgalmi időszakok CV-értékeinek intervallumai a teljes vizsgált időszakra és a 30 éves referencia időszakokra vonatkozóan.

Table 4: The intervals of CV of water cycle periods in the whole and reference periods.

\begin{tabular}{|c|c|c|c|c|}
\hline \multirow{2}{*}{ idősor } & \multicolumn{4}{|c|}{ vízforgalmi időszakok } \\
\cline { 2 - 5 } & tárolási & fö vízfelhasználási & fenntartási & hidrológiai év \\
\cline { 2 - 5 } & $\mathbf{6}$ hónap & $\mathbf{3}$ hónap & 3 hónap & 12 hónap \\
\hline $1901-2010$ & $25-33$ & $30-42$ & $35-45$ & $16-24$ \\
\hline $\begin{array}{c}30 \text { éves referencia } \\
\text { időszakok }\end{array}$ & $21-35$ & $26-47$ & $28-58$ & $14-27$ \\
\hline
\end{tabular}

Referencia időszakok (30 éves időszakok) vizsgálata

A referencia időszakok alkalmasak a CV-értékek időbeli változásának bemutatására, $s$ ezzel a referencia időszakok változékonyságának, esetlegesen szélsőségesebbé válásának vizsgálata is lehetővé válik. Az alábbiakban a referencia időszakokat a vízforgalmi időszakok csapadékeloszlásaival jellemzem (2. ábra).

2010 nélkül
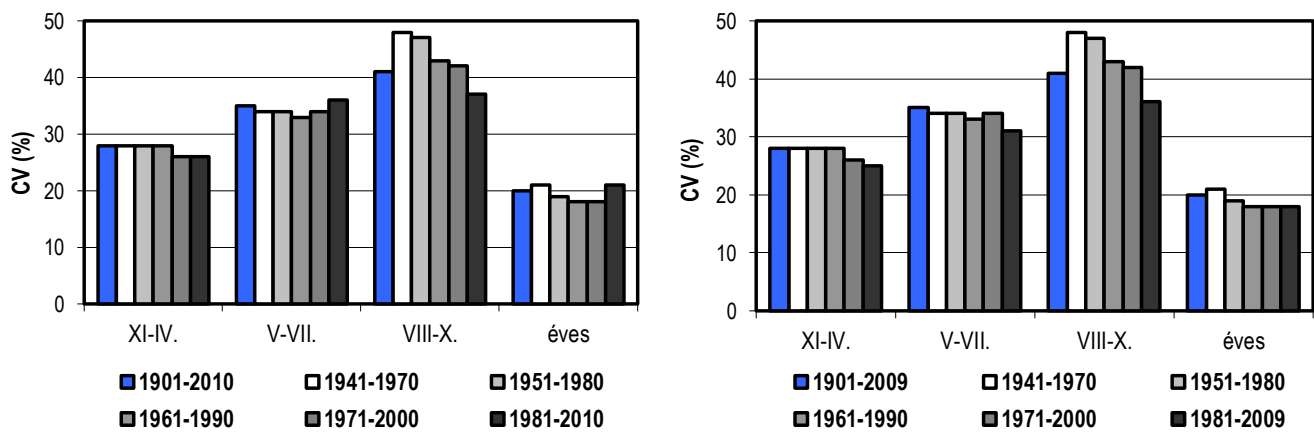

2-3. ábra: A vízforgalmi időszakok átlagos CV-értékeinek változása a referencia időszakokban (31 mérőállomás, 2010 adataival és nélküle).

Figure 2-3: Changes of the mean CV of the water cycle periods in the reference periods (31 stations, including and excluding 2010 data). 
A 30 éves referencia időszakokon belül a tárolási és a fenntartási időszakban a CV értéke csökkenő tendenciát mutat, míg a hidrológia év esetében az utolsó 30 év (1981-2010) az egyébként csökkenő tendencia megfordulását jelzi.

A fő vízfelhasználási időszakban a 31 mérőállomás esetében az utolsó referencia időszak (1981-2010) átlagos CV-értéke a referencia időszakok között a legnagyobb. Érdekesség, hogy ugyanerre az időszakra vonatkozóan a 8 nagyvárosi állomásnál a CV értéke a korábbi referencia időszakokénál kisebb (nincs hozzá ábra).

Meg kell említeni, hogy az utolsó referencia időszak megitélésében a 2010-es év rendkívüli csapadékbősége jelentős szerepet játszik. A változékonyság növekedése felé mutató tendenciák ezzel az egy évvel magyarázhatók, amit a 31 mérőállomás 2010 nélküli adataival szemléltetek (3. ábra). A 2010-es év sok méröhelyen sokéves maximumot jelentő csapadékának kivételével a CV-értékek már minden vízforgalmi időszakban csökkenő tendenciát mutatnak.

A mérőállomások átlaga az országos léptékủ folyamatokra mutat rá, amennyiben elfogadjuk, hogy a vizsgált mérőállomások reprezentálják az országot. Az egyedi - lokális különbségek bemutatására két eltérő adottságú mérőhelyet, az egyik legcsapadékosabb Csurgót (sokéves átlagcsapadék $796 \mathrm{~mm}$ ) és az egyik legszárazabb Ásotthalmát (sokéves átlagcsapadék $564 \mathrm{~mm}$ ) választottam ki (4-5. ábra).

Csurgó

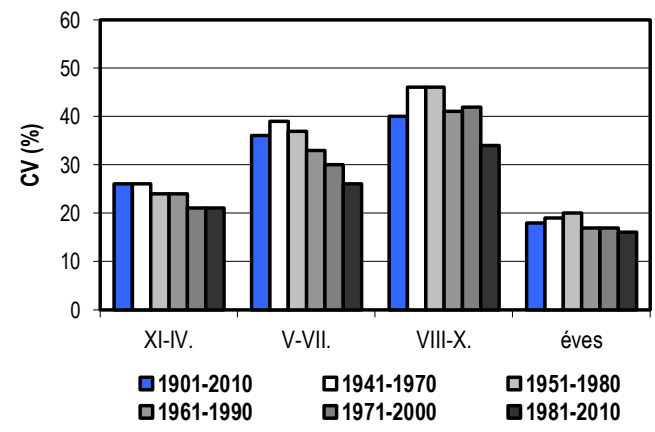

Ásotthalom

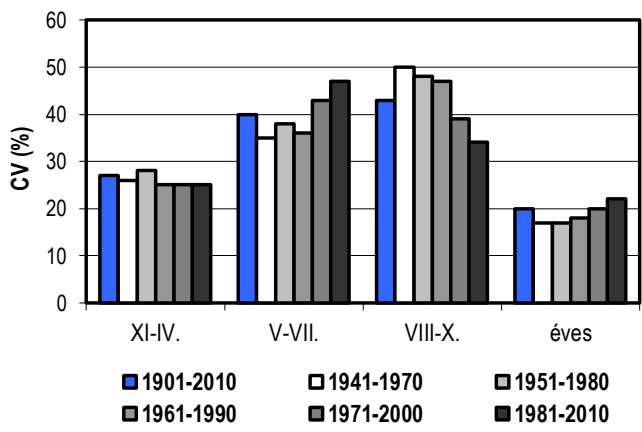

4-5. ábra: A vízforgalmi időszakok CV-értékeinek változása a referencia időszakokban Csurgón és Ásotthalmán.

Figure 4-5: Changes of CV of the water cycle periods in the reference periods in Csurgó and Ásotthalom station.

A két mérőállomáson - hasonlóan az általános összefüggésekhez - a tárolási és a fenntartási időszakban a CV-értékek csökkenő tendenciát mutatnak. A döntő különbség a fö vízfelhasználási időszakban jelentkezik: míg Csurgó esetében a CV-értékek egyértelműen csökkennek az egymást követő referencia időszakokban, addig Ásotthalmán ennek épp az ellenkezője állapítható meg. Mindez a különbség a hidrológiai év adatsoraiban is megjelenik, $s$ rámutat a lokális folyamatok ismeretének jelentőségére. 
5. táblázat: A havi átlag \%-ában kifejezett alsó kvartilis a teljes vizsgált időszakban (1901-2010) az erdőgazdasági nagytájak szerint csoportositott mérőállomásokon.

Table 5: The lower quartile expressed in the \% of the monthly mean in the whole period (1901-2010), sorted by forest regions.

\begin{tabular}{|c|c|c|c|c|c|c|c|c|c|c|c|c|c|}
\hline $1901-2010$ & tszfm & I. & II. & III. & IV. & V. & VI. & VIII. & VIII. & IX. & $X$. & $\mathrm{XI}$. & XII. \\
\hline Vásárosnamény & 114 & 59 & 53 & 43 & 61 & 65 & 62 & 54 & 57 & 53 & 43 & 54 & 63 \\
\hline Tiszabercel & 102 & 57 & 45 & 43 & 66 & 57 & 62 & 60 & 49 & 53 & 40 & 49 & 59 \\
\hline Téglás & 144 & 56 & 48 & 46 & 57 & 54 & 60 & 58 & 54 & 50 & 44 & 49 & 59 \\
\hline Túrkeve & 87 & 51 & 55 & 45 & 57 & 53 & 65 & 54 & 54 & 48 & 36 & 53 & 56 \\
\hline Ásotthalom & 117 & 48 & 53 & 48 & 61 & 54 & 57 & 50 & 55 & 48 & 43 & 45 & 58 \\
\hline Soltvadkert & 116 & 50 & 50 & 48 & 68 & 61 & 68 & 54 & 58 & 53 & 45 & 49 & 56 \\
\hline Tengelic & 120 & 57 & 49 & 54 & 63 & 60 & 63 & 58 & 55 & 51 & 47 & 50 & 54 \\
\hline Tarcal & 115 & 54 & 46 & 38 & 62 & 59 & 61 & 54 & 53 & 42 & 39 & 48 & 58 \\
\hline Bélapátfalva & 318 & 49 & 40 & 38 & 59 & 64 & 62 & 57 & 54 & 50 & 33 & 51 & 58 \\
\hline Sáta & 276 & 45 & 46 & 40 & 63 & 62 & 60 & 56 & 52 & 54 & 39 & 53 & 59 \\
\hline Bogács & 186 & 50 & 48 & 43 & 58 & 56 & 63 & 54 & 49 & 50 & 42 & 53 & 61 \\
\hline Kisgyőr & 173 & 49 & 35 & 42 & 53 & 56 & 62 & 51 & 49 & 55 & 32 & 52 & 51 \\
\hline Ecséd & 157 & 55 & 44 & 52 & 63 & 62 & 55 & 52 & 56 & 50 & 32 & 54 & 63 \\
\hline Tolmács & 196 & 65 & 47 & 47 & 54 & 58 & 58 & 53 & 46 & 45 & 36 & 56 & 62 \\
\hline Nógrád & 236 & 64 & 55 & 44 & 62 & 59 & 54 & 57 & 56 & 42 & 38 & 57 & 56 \\
\hline Páty & 194 & 59 & 52 & 51 & 61 & 63 & 54 & 53 & 52 & 43 & 43 & 55 & 66 \\
\hline Csákvár & 185 & 62 & 49 & 53 & 60 & 66 & 54 & 50 & 56 & 46 & 40 & 56 & 65 \\
\hline Szár & 201 & 64 & 51 & 52 & 61 & 60 & 54 & 46 & 48 & 45 & 38 & 56 & 62 \\
\hline Ravazd & 131 & 59 & 47 & 58 & 55 & 55 & 58 & 55 & 57 & 46 & 48 & 59 & 59 \\
\hline Bakonybél & 267 & 57 & 52 & 51 & 61 & 56 & 56 & 48 & 56 & 47 & 46 & 62 & 63 \\
\hline Városlőd & 294 & 57 & 57 & 61 & 62 & 50 & 63 & 50 & 63 & 56 & 49 & 61 & 61 \\
\hline Ács & 120 & 59 & 46 & 55 & 53 & 57 & 60 & 57 & 61 & 44 & 44 & 56 & 60 \\
\hline Beled & 133 & 50 & 43 & 59 & 57 & 57 & 63 & 62 & 61 & 53 & 46 & 58 & 62 \\
\hline Kerta & 140 & 58 & 50 & 54 & 58 & 65 & 67 & 57 & 62 & 54 & 45 & 58 & 65 \\
\hline Csehimindszent & 175 & 48 & 44 & 55 & 62 & 57 & 67 & 56 & 61 & 49 & 44 & 56 & 58 \\
\hline Kercaszomor & 238 & 54 & 48 & 58 & 57 & 61 & 72 & 62 & 67 & 52 & 49 & 53 & 56 \\
\hline Tapolca & 125 & 56 & 38 & 50 & 59 & 61 & 64 & 54 & 55 & 53 & 47 & 51 & 59 \\
\hline Tab & 177 & 52 & 43 & 46 & 61 & 60 & 61 & 58 & 60 & 54 & 42 & 57 & 57 \\
\hline Csurgó & 147 & 64 & 53 & 49 & 62 & 63 & 66 & 54 & 52 & 54 & 45 & 54 & 59 \\
\hline Szálka & 168 & 56 & 52 & 53 & 64 & 62 & 60 & 60 & 57 & 45 & 47 & 48 & 58 \\
\hline Pécsvárad* & 259 & 62 & 54 & 60 & 63 & 58 & 63 & 58 & 57 & 48 & 41 & 53 & 59 \\
\hline
\end{tabular}

* Pécsvárad adatsorából hiányzik a 2007-2010 közötti időszak 
6. táblázat: A havi átlag \%-ában kifejezett felső kvartilis a teljes vizsgált időszakban (1901-2010) az erdőgazdasági nagytájak szerint csoportositott mérőállomásokon.

Table 6: The upper quartile expressed in the \% of the monthly mean in the whole period (1901-2010), sorted by forest regions.

\begin{tabular}{|c|c|c|c|c|c|c|c|c|c|c|c|c|c|}
\hline 1901-2010 & tszfm & I. & II. & IIII. & IV. & V. & VI. & VII. & VIII. & IX. & $X$. & XI. & XII. \\
\hline Vásárosnamény & 114 & 125 & 136 & 135 & 124 & 124 & 128 & 133 & 138 & 128 & 145 & 141 & 132 \\
\hline Tiszabercel & 102 & 131 & 140 & 138 & 126 & 134 & 127 & 130 & 133 & 135 & 134 & 138 & 126 \\
\hline Téglás & 144 & 130 & 146 & 141 & 135 & 141 & 131 & 133 & 141 & 133 & 154 & 140 & 127 \\
\hline Túrkeve & 87 & 135 & 146 & 146 & 134 & 136 & 130 & 130 & 132 & 131 & 144 & 136 & 133 \\
\hline Ásotthalom & 117 & 140 & 131 & 144 & 126 & 134 & 130 & 127 & 125 & 133 & 140 & 135 & 138 \\
\hline Soltvadkert & 116 & 136 & 142 & 132 & 136 & 129 & 120 & 127 & 140 & 137 & 136 & 134 & 133 \\
\hline Tengelic & 120 & 127 & 137 & 132 & 132 & 130 & 128 & 133 & 133 & 134 & 134 & 138 & 142 \\
\hline Tarcal & 115 & 131 & 148 & 140 & 134 & 139 & 135 & 133 & 127 & 137 & 142 & 136 & 130 \\
\hline Bélapátfalva & 318 & 136 & 155 & 150 & 135 & 121 & 132 & 125 & 137 & 129 & 148 & 143 & 131 \\
\hline Sáta & 276 & 131 & 149 & 146 & 129 & 120 & 132 & 139 & 134 & 131 & 140 & 144 & 123 \\
\hline Bogács & 186 & 130 & 160 & 141 & 139 & 127 & 127 & 145 & 136 & 129 & 150 & 137 & 128 \\
\hline Kisgyőr & 173 & 123 & 144 & 137 & 126 & 128 & 131 & 145 & 130 & 136 & 154 & 141 & 132 \\
\hline Ecséd & 157 & 138 & 149 & 142 & 137 & 129 & 138 & 137 & 141 & 132 & 144 & 136 & 137 \\
\hline Tolmács & 196 & 138 & 138 & 137 & 127 & 131 & 135 & 134 & 131 & 130 & 141 & 133 & 129 \\
\hline Nógrád & 236 & 131 & 138 & 139 & 134 & 141 & 123 & 132 & 139 & 136 & 140 & 140 & 140 \\
\hline Páty & 194 & 139 & 144 & 129 & 132 & 129 & 128 & 134 & 127 & 141 & 141 & 134 & 127 \\
\hline Csákvár & 185 & 126 & 135 & 126 & 138 & 131 & 138 & 126 & 121 & 139 & 138 & 136 & 126 \\
\hline Szár & 201 & 137 & 139 & 130 & 133 & 123 & 131 & 134 & 134 & 138 & 137 & 137 & 130 \\
\hline Ravazd & 131 & 137 & 142 & 133 & 143 & 130 & 133 & 130 & 134 & 140 & 139 & 124 & 138 \\
\hline Bakonybél & 267 & 131 & 138 & 139 & 136 & 132 & 121 & 130 & 138 & 141 & 130 & 132 & 133 \\
\hline Városlöd & 294 & 131 & 138 & 129 & 128 & 135 & 135 & 123 & 125 & 137 & 138 & 132 & 125 \\
\hline Ács & 120 & 137 & 129 & 139 & 139 & 131 & 129 & 132 & 131 & 140 & 142 & 127 & 129 \\
\hline Beled & 133 & 142 & 142 & 133 & 147 & 130 & 127 & 127 & 125 & 121 & 141 & 125 & 134 \\
\hline Kerta & 140 & 136 & 140 & 134 & 129 & 132 & 127 & 136 & 118 & 125 & 141 & 130 & 139 \\
\hline Csehimindszent & 175 & 135 & 140 & 131 & 127 & 135 & 128 & 141 & 126 & 131 & 141 & 134 & 137 \\
\hline Kercaszomor & 238 & 142 & 134 & 132 & 131 & 133 & 130 & 136 & 123 & 132 & 152 & 143 & 136 \\
\hline Tapolca & 125 & 131 & 147 & 133 & 129 & 132 & 132 & 135 & 131 & 137 & 142 & 140 & 132 \\
\hline Tab & 177 & 134 & 140 & 132 & 133 & 130 & 129 & 125 & 129 & 133 & 139 & 136 & 138 \\
\hline Csurgó & 147 & 129 & 138 & 135 & 131 & 131 & 123 & 126 & 129 & 136 & 144 & 141 & 131 \\
\hline Szálka & 168 & 134 & 137 & 131 & 125 & 134 & 126 & 136 & 128 & 133 & 135 & 132 & 139 \\
\hline Pécsvárad* & 259 & 131 & 133 & 128 & 138 & 130 & 124 & 128 & 126 & 122 & 133 & 133 & 141 \\
\hline
\end{tabular}




\section{$A z$ interkvartilis terjedelem vizsgálata}

Az alsó és a felső kvartilist, s így az interkvartilis terjedelmet az átlag százalékos arányában vizsgáltam abból a megfontolásból, hogy az átlagra vonatkozó százalékos prognózisokat viszonyítani tudjuk ehhez a statisztikai mutatóhoz.

\section{Havi csapadékadatok}

A teljes időszakot (1901-2010) vizsgálva az alsó kvartilis minimuma a havi csapadékhoz viszonyítva a mérőállomástól függően 32-54\% között mozog, míg maximuma 49-72\% közötti értéket vesz fel. A mérőállomásokat összesítve az alsó kvartilis a havi csapadék átlagosan 42-61\%-a. A CV-értékkel összhangban a legkisebb alsó kvartilis értékek októberben, a legnagyobbak április-június hónapokban jelennek meg (5. táblázat).

A teljes időszakot (1901-2010) vizsgálva a felső kvartilis minimuma a havi csapadékhoz viszonyítva a méröállomástól függően 118-130\% között mozog, míg maximuma 138-160\% közötti értéket vesz fel (6. táblázat). A méröállomásokat összesítve a felső kvartilis a havi csapadék átlagosan 129-141\%-a. A CV-érték és a felső kvartilis között az összhang kevésbé látható, mint az alsó kvartilis esetében.

A 31 mérőállomást és az összes hónapot együtt értékelve az alsó kvartilis az átlag $54 \%$-a, míg a felső kvartilis az átlag $134 \%$-a, tehát nagy általánosságban a havi csapadékadatok 50\%-a az átlag 54-134\%-a közé esik, ami mutatja a csapadék jelentős változatosságát.

\section{Vízforgalmi időszakok}

Hosszabb időszakokat vizsgálva - a CV-értékhez hasonlóan - az interkvartilis terjedelem is csökken, azaz az időszak hosszának növekedésével az időszaki csapadékok egyre szükülő intervallummal fogják közre az átlagot (7. táblázat).

7. táblázat: Az időszaki csapadékok alsó és felső kvartiliseinek az átlag \%-ában kifejezett intervallumai a teljes vizsgált időszakra (1901-2010) vonatkozóan.

Table 7: The intervals of the lower and upper quartile of the water cycle periods expressed in the \% of the mean in the whole period (1901-2010).

\begin{tabular}{|c|c|c|c|c|c|}
\hline \multirow{2}{*}{ idősor } & \multirow{2}{*}{ kvartilis } & \multicolumn{4}{|c|}{ vízforgalmi időszakok } \\
\cline { 3 - 6 } & & tárolási & fő vízfelhasználási & fenntartási & hidrológiai év \\
\cline { 3 - 6 } & $\mathbf{6}$ hónap & $\mathbf{3}$ hónap & 3 hónap & 12 hónap \\
\hline \multirow{2}{*}{$1901-2010$} & alsó & $75-84$ & $67-79$ & $66-78$ & $82-90$ \\
\cline { 2 - 6 } & felső & $113-123$ & $116-131$ & $115-134$ & $110-115$ \\
\hline
\end{tabular}

A 7. táblázatban megadott intervallumok átlagát nézve megállapítható, hogy a tárolási időszak csapadékának 50\%-a az átlag 79-118\%-a közé esik. A fő vízfelhasználási időszaknál ugyanez $74-122 \%$, a fenntartási időszakban $72-124 \%$, míg a hidrológiai év esetében 
$86-113 \%$. Ez nagy általánosságban azt jelenti, hogy a vízforgalmi időszakokban az időszaki átlagtól $\pm 20 \%$-kal eltérő csapadék még az interkvartilis terjedelem része. A hidrológiai évnél ez az intervallum $\pm 15 \%$ alá csökken.

\section{A számított statisztikai mutatók megjelenítése}

A CV-értéknél már példaként szereplő Csurgó és Ásotthalom mérỏállomások havi adataival szemléltetem a számított statisztikai mutatókat. Most is az átlag százalékában kifejezett értékeket használom, hogy az átlagtól való eltérés jobban érzékelhető legyen (6-7. ábra).

Az ábrákon az interkvartilis terjedelem okker színnel jelenik meg. A sáv szélessége mutatja, hogy az adatok 50\%-a az átlaghoz képest hol helyezkedik el. A minimumokhoz és a maximumokhoz tartozó értékek jelzik, hogy a csapadék szélsőségekre hajlamos meteorológiai jellemző.

A CV-értékek kétcsúcsú görbét rajzolnak ki a 110 év adatai alapján, vagyis a február és az október csapadéka mutatja a legnagyobb változékonyságot.
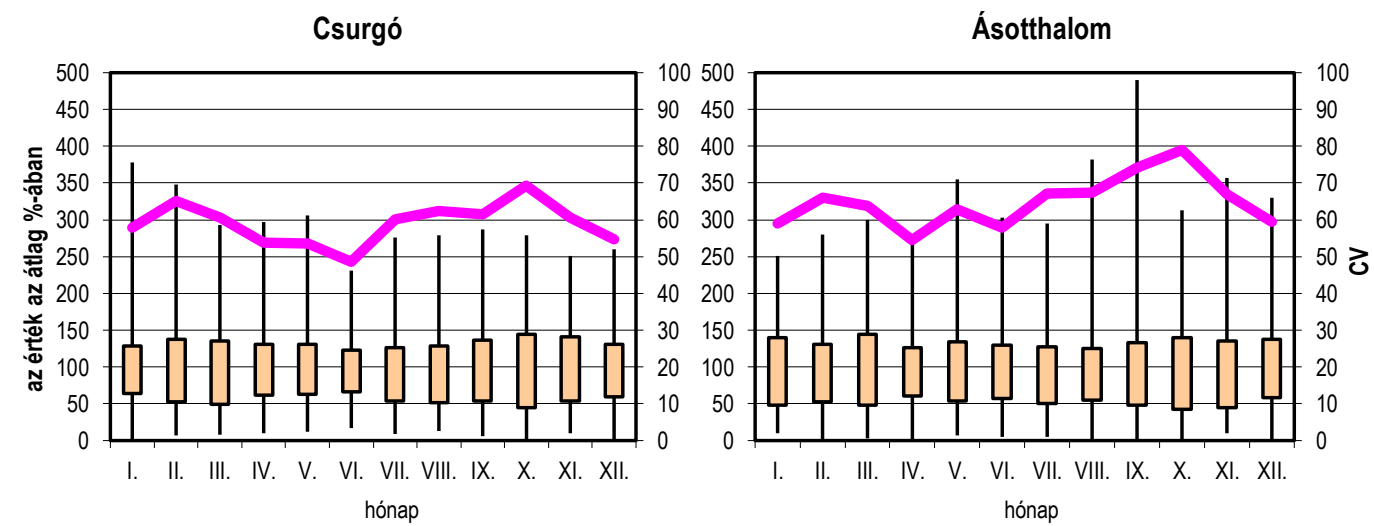

6-7. ábra: A számított statisztikai mutatók az átlag \%-ában (Csurgó, Ásotthalom, 1901-2010).

Figure 6-7: Statistical parameters expressed in the \% of the mean (Csurgó, Ásotthalom, 1901-2010).

\section{ÖSSZEFOGLALÁS}

A fejezetekben már említett következtetéseket az alábbiakban lehet összefoglalni:

- A vizsgált időszak hossza és a CV-értéke fordítottan arányos.

- A rövidebb időszakok (hónap, 3 hónapos vízforgalmi időszakok) átlaga nem jó jellemzője az adatsornak, mert a CV lényegesen meghaladja a 30\%-ot.

- A hosszabb időszakra vonatkozó átlag megbízhatóbbá válik, mert eliminálja a változatosság egy részét. 
- A 30 éves referencia időszakok vízforgalmi időszakokra vonatkozó CV-értékei az idővel általában inkább csökkennek (különösen a tárolási és a fenntartási időszakban), azaz a csapadék mennyisége általánosságban nem vált szélsőségesebbé, de ebben jelentős lokális különbségek vannak, illetve lehetnek. A rendkívüli csapadékot hozó 2010-es év hatása rámutat arra, hogy akár egy év is döntően befolyásolhatja az értékelést.

- Még az időszaki csapadék változatossága is olyan mértékü, hogy az átlagtól való $\pm 20 \%$-os eltérés is az interkvartilis terjedelembe esik, tehát az ilyen léptékủ változás az adatok $50 \%$-a által meghatározott intervallumon belül marad, ezért szélsőségesnek nem nevezhetö.

\section{FELHASZNÁLT IRODALOM}

Deka R.L., Mahanta C., Pathak H., Nath K. K. \& Das S. 2013: Trends and fluctuations of rainfall regime in the Brahmaputra and Barak basins of Assam, India. Theoretical and Applied Climatology 114(1-2): 61-71. DOI: $10.1007 / \mathrm{s} 00704-012-0820-x$

Dunkel Z., Tiringer Cs. \& Zárbok Zs. 1991: Agrometeorológiai állomáshálózat racionális sürüségének meghatározása, Időjárás 95(5): 226-236.

Hajósy F., Kakas J. \& Kéri M. 1975: A csapadék havi és évi összegei Magyarországon a mérések kezdetétöl 1970-ig. Országos Meteorológiai Szolgálat, Budapest.

Huzsvai L. (szerk.) 2011: Statisztika mezőgazdászok részére. SENECA BOOKS, Debrecen.

Időjárási havijelentések (1971-2012), OMSZ kiadványok, Budapest.

Járó Z. 1989: Az erdő vízforgalma. Az Erdő 33(8): 352-355.

Machiwal D., Dayal D. \& Kumar S. 2017: Long-term rainfall trends and change points in hot and cold arid regions of India, Hydrological Sciences Journal 62(7): 1050-1066. DOI: 10.1080/02626667.2017.1303705

Szász G. \& Tőkei L. (szerk.) 1997: Meteorológia mezőgazdáknak, kertészeknek, erdészeknek. Mezőgazda Kiadó, 439-443.

Vízrajzi évkönyvek (1966-2006), VITUKI kiadványok, Budapest.

Webb E.E., Heard K., Natali S. M., Bunn A.G., Alexander H.D., Berner L.T. et al. 2017: Variability in aboveand belowground carbon stocks in a Siberian larch watershed. Biogeosciences 14: 4279-4294. DOI: 10.5194/bg-14-4279-2017

Érkezett: 2017.március 20.

Közlésre elfogadva: 2017. október 24. 